\title{
OHIAJHOCHOCH CJABHOWTH
}

\begin{abstract}
Сажетак: У раду „Онлајн односи с јавношћу“, тема истраживаюь су односи с јавношћу у дигиталној ери, посебно онлајн (online) - основне карактеристике и особености, потенцијал веба (web) за е-ПР, изазови и предности дигиталне комуникације. Кратак преглед одабраних теоријских радова у којима се критички промишььају и дефинишу онлајн односи с јавношћу, такође је овде представљен. Анализиран је и потенцијал мреже за дијалог, јавну расправу и интерактивност, као и потениијал блогова и друштвених мрежа за односе с јавношћу у дигиталном 21. веку. У закључку рада дат је кратак критички приказ места, улоге и потенцијала онлајн ПР-а.
\end{abstract}

Кључне речи: односи с јавношћу ( ПР), е-ПР, онлајн, интернет, друштвени медији, комуникација

\section{Сигнали који знају за себе}

Заједница корисника Интернета биће водећа струја свакодневног живота. Његова демографија ће све вите личити на демографију самог света...Истинска вредност мреже мање лежи у информачијама а више у заједници. Информативни аутопут је више него пречица ка свакој књизи у Конгресној библиотещи. Он ствара потпуно нову глобалну соиијалну фабрику. ${ }^{1}$

Писао је, пре скоро две деценије, и сасвим тачно предвидео, Николас Негропонте, у поглављу Сигнали који знају за се$б е$, данас већ култне књиге Бити дигиталан. Заједница корисника интернета данас јесте водећа струја свакодневног живота и њихове активности у великој мери обликују различите видове дигиталне комуникације, чије су суштинске

1 Негропонте, Н. (1998) Бити дигиталан, Београд, стр. 173. 
особености - интерактивност, транспарентност, велика брзина, презасићеност информацијама (information overload), нестајање временских и географских ограничења, умрежавање и сл. Презасићеност информацијама представља једну од кључних одлика дигиталног доба и екранске културе. Све ређе се поставља питање разумевања информације, јер се скратило и променило време њеног пута, или тачније юихових путева. ${ }^{2}$

Уз то, корисник интернета добио је могућност да не буде више само пасивни учесник у једносмерној комуникацији, већ да директно утиче на њен ток и садржај. Могућност да буде активан учесник у комуникацији, која је двосмерна и интерактивна, у правом и најлепшем значењу тих речи двадесет и четири сата, на било ком крају света, на различитим језицима и у различитим културолошким контекстима. Могућност да обликује садржај дијалога, да утиче на време и структуру комуникационог канала. С друге стране, преоптерећење информацијама (и потреба за управљанем у таквим условима) је основни изазов који уноси дигитална димензија у комуникацијама. ${ }^{3}$

Интерактивност чини интернет радикално другачијим медијем у односу на све досадашње, условно речено, традиционалне преносиоце поруке. И управо ова карактеристика је пресудно утицала на промене у области односа с јавношћу. Данас Интернет не само да постаје најважнији вид комуникачије са потрошачем и најефектнија тачка утииаја на юега, већ се, у не тако далекој будућности, предвића да он у себи обједини све остале комуникационе медије. ${ }^{4}$

Технолошки напредак пресудно је утицао и на односе с јавношћу. Нове комуникацијске технологије омогућиле су стварање конкурентних тржишта на којима подједнако егзистирају мала и велика подузећа, цивилне и јавне организације, те други дионици. У складу с ијеловитом концепиијом комуникације нових односа с јавношћу и маркетинга, тежиште производње више није на масовној производњи, него на персонализираној производњи и дистрибуцији. У интерактивним односима с јавношћу главно мјесто заузима комуникацијски модел “један на један” и “многи на многе”, док су основно полазиште - захтјеви и жеље припадника

2 Вученовић, Т. (2011) Грађанско новинарство у дигиталном 21. веку, Култура бр. 132, Београд: Завод за проучавање културног развитка

3 Лалић, Д. (2010) Сочијалне мреже у функиији унапређења интерних односа с јавношћу, Нови Сад: Универзитет у Новом Саду, Факултет техничких наука, стр. 101.

4 Костић М., Онлајн ПР, 12.03.2012., http://www.veza.biz/mkostic/35.html 
публике јавности који се настоје прихватити као партнери, или им се такав однос само жели предочити. ${ }^{5}$

У овако скицираном друштвеном контексту дигиталне ере, улога ПР-а постаје још значајнија и комплекснија. Односи с јавношћу на интернету су, пре свега, област и пракса у настајању, која се непрекидно мења. За успешно бављење односима са јавношћу на интернету, неопходно је стицање адекватних знања из области управљања онлајн репутацијом и комуникацијом. ПР практичари (PR practitioners) трагају за одговорима на актуелна питања: Како дати праву информацију у правом часу и на прави начин, у дигиталном свету? На који начин се изборити за публицитет? Како да наша информација упућена циљној јавности буде примећена и усвојена, у изузетно великом броју вести којима смо непрекидно изложени?

\section{Word of Mouth VS Word of Mouse}

Бројне дефиниције одређују, на мање или више сличан начин, појам односа с јавношћу. Оно што је потребно да нагласимо је чињеница да се односи с јавношћу баве људима. ${ }^{6}$ Проф. др Винка Филиповић и проф. др Милица Костић, издвајају следеће одређење овог појма - ПР представља умеће рада и говора који ће створити повољно мишьене код људи о некој организачији, институцији или појединиу. ${ }^{7}$

Односи с јавношћу представљају планиран и трајан напор да се успостави и одржи наклоност и разумевање између организаиије и юених ииљьих јавности. ${ }^{8}$ Сем Блек (Sam Black), почасни професор на Универзитету Стирлинг (University of Stirling) и један од пионира у области односа с јавношћу у Великој Британији, сматра да је веома тешко дефинисати односе с јавношћу и да већина, ако не и све дефиниције, представљају, у ствари, описе ефеката, а не праве дефиниције. Овај аутор највише је наклоњен следећој дефиницији: Пракса односа с јавношћу је уметност и знање којим се, кроз узајамно разумевање засновано на истинитом и потпуном обавештавағу, постиже хармонија са околином. ${ }^{9}$ Модерни концепт односа с јавношћу сврстава ову дисциплину у област менаџмента. Са технолошким развојем и

\footnotetext{
5 Demeterffy Lančić, R. (2010) Novi mediji i odnosi s javnošću, Medijske studije, Zagreb: Sveučilište u Zagrebu, Fakultet političkih znanosti, str. 157.

6 Филиповић, В. и Костић Станковић, М. (2008) Односи с јавношћу, Београд, стр. 3.

7 Исто, стр. 4.

8 Блек, С. (2003) Односи с јавношћу, Београд: Клио, стр. 44.

9 Исто, стр. 11.
} 
напретком, настајала су и нова подручја и занимања у оквиру ПР-а - онлајн ПР консултант, дигитални стратег, е-ПР итд. Термин онлајн комуникације је све више у употреби као термин који обухвата и маркетинг и односе с јавношћу на интернету, а питање које је и даље кључно, и у реалном и у виртуелном свету је - како ћемо најбоље да пласирамо информацију? Јер, Ви сте оно што објављујете. Људи траже аутентичност а не добро сложену причу. Желе сарадюу а не пропаганду. ${ }^{10}$

Дефиниција Мајкла Левина (Michael Levine), писца књиге “Guerrilla P. R. Wired“, коју наводи Миодраг Костић у серији текстова под називом Шma је ПР - online public relations- гласи - ПР је уметност да се људима понуде разлози да увере сами себе. Онлајн ПР, наставља овај аутор, представља скуп свих акиија које бисте предузели на Интернеmу, са ичием да се ваша порука пренесе ьудима који би за юу били заинтересовани... Укратко, онлајн ПР није о томе како довести посетиоче да виде ваш сајт, већ како да се, користећи ваш веб сајт, о вама прича на најгледанијој телевизијској емисији у земљи. ${ }^{11}$

Комуникација путем веба, те упораба нових технологија (друштвених мрежа) ради учинковитијег комуницираға с дионичарима - је дефиниција која је дата у Речнику појмова, на сајту Хрватског друштва за односе с јавношћу (ХУОJ, Хрватска удруга за односе с јавношћу). ${ }^{12}$

Односи с јавношћу на интернету представљају сегмент ПР-а са највећом перспективом, сматра Ђорђе Таловић, ПР консултант, али упркос томе, у Србији је овај начин комуницирања с ичиљним јавностима и даље запостављен. ${ }^{13}$ Подизање свести о значају и улози интернета као медија, који релативизује значај свих других медија, је посао који је још увек пред нама. Као добар пример ПР праксе, која се појавила и код нас, поменути аутор наводи - пренос догађаја уживо, путем интернета. Ова врста ПР активности у свету се примењује одавно, а највеће светске компаније имају своје онлајн телевизије, које уколико не емитују програм 24 часа дневно, приказују и чувају бројне прилоге о компанији и юеним активностима, које посетилаи може да погледа

\section{0 Исто, стр. 44.}

11 Костић, М. нав. дело, 13.03.2012.

12 17.05.2012. http://www.huoj.hr/baza-znanja/rjecnik-pr-pojmova-hr101

13 Талевић, Ђ. Односи с јавношћу: Онлајн ПР, у: Употреба информационокомуникационих технологија у Републищи Србији, (2008), Београд: Републички завод за статистику Србије, 24.07.2009., 03.04.2012., http://bif. rs/2009/07/odnosi-s-javnoscu-onlajn-pr 
када год пожели. ${ }^{14}$ Једна од веома важних фаза, закључује Таловић, у оквиру односа с јавношћу је - евалуација и мерење ефеката ових односа, на различите начине. Једна од могућности за мерење квантитета јесте бројање посета одговарајућем сајту, коју обезбеђује Гугл аналитикс, као и сву пратећу статистику. ${ }^{15}$

У Википедији (Wikipedia) под одредницом Интерактивни ПР пише - подразумева се употреба бројних интернет алатки и технологија - претраживача, друштвених медиjа, блогова, веб 2.0 и сл., које омогућавају директну комуникаиију са циљним јавностима и публиком, без искључивог ослањања на мејнстрим медије и издања. ${ }^{16}$

Термин интерактивни ПР имплицира двосмерну комуникацију, између организације и јавности. У Европи, Дејвид Филипс (David Phillips) је написао Управљање репутащијом y cajбер nросторy (Managing Reputation in Cyberspace)1999., Онлајн односе с јавношћу (Online Public Relations), 2001., и, са Филипом Јангом (Philip Young), Односе с јавношћу друго издане (Online Public Relations Second Edition), 2009., у којој је описана форма и природа интернетом посредованих односа с јавношћу. Друге две публикације укључиле су друштвене медије, као и многе друге платформе за комуникацију - као што је нпр. мобилни телефон, онлајн машине за игрице и сл. Интерактивни ПР обухвата све форме комуникације, није ограничен само на онлајн саопштење за јавност, користи све елементе за изградњу односа али чува значај изговорене речи. ${ }^{17}$

Интернет методе су се појавиле као брз и прикладан начин пут обраћања јавности, али су боље окарактерисане термином дигитални ПР. Иако је дијалог подстакнут онлајн, повратна спрега може се дешавати офлајн, и, такође, може да буде мања од жељене. Потенцијално велики број корисника којима желите да се обратите ( без придржавања неких важних правила које су установили истраживачи и практичари) - не подразумева и успешне онлајн односе с јавношћу.

Данас, стога, имамо ситуацију у којој традиционалне технике којима су се маркетинг и односи с јавношћу користили шездесетак година, вите не вриједе, па сувремени односи с јавношћу више не зависе толико од буцета организачије, скретања позорности медија, него од способности

14 Исто, 03.04.2012.

15 Исто, 05.04.2013

16 12.02.2012., http://en.wikipedia.org/wiki/Interactive_public_relations

17 Исто, 13.02.2012. 
властитих служби да наведу људе да их сами нађу, али и да производе и дистрибуирају информащије. У традиционалним односима с јавношћу и у маркетингу, ова се техника зове "Word of Mouth" ("од уста до уста"), и претпоставља аквизицију нових клијената препорукама постојећих. У модерном интернетском смислу назива се "Word of Mouse”... Интернет је односе с јавношћу поновно учинио јавнима, након што су годинама били усредоточени искључиво на медије. $^{18}$

Утицај нових технологија на функцију односа с јавношћу, истраживала је и др Мајда Тафра Влаховић, предавач на Универзитету у Дубровнику. Посао ПР практичара у виртуелном свету постао је још осетљивији и сложенији, сматра др Влаховић, могућности комуникације су се повећале као и ризици које њена транспарентност и свеприсутност, носе са собом. Е-ПР менаимент се односи на управљање репутацијом као интегралном компонентом односа управљања и стратешког смјера, који су изравно под утјеияајем интернета. $^{19}$ У ери информационо - комуникационих технологија, истраживање и анализа за потребе ПР-а су олакшане, али је комуникачијска технологија покренула снаге које су у стану дјеловати против организаиија досад незамисливом брзином и досегом. ${ }^{20}$ Ипак, док прате достигнућа нових технологија, ПР професионалци ће се, такође, наћи и пред бројним изазовима - пред питањима приватности, ауторских права, протока сумњивих информација, контроле и надзора на глобалној рачунарској мрежи, информацијске саботаже и многим другим.

У прегледној књизи, посвећеној односима с јавношћу на интернету Мет Хајг (Matt Haig), ${ }^{21}$ у уводном поглављу пише о односима с јавношћу као кључу пословног успеха у онлајн свету. Наравно, додаје, добра комуникаиија је одувек била важна за пословни свет али са појавом интернета она је постала - суштина. Овај нови медијум зато доноси и нову форму маркетинга, у којој је онлајн тачка сусрета између предузећа и јавности - све..$^{22}$ Указујући на значај и суштину

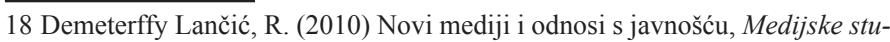
dije, Zagreb: Sveučilište u Zagrebu, Fakultet političkih znanosti, str. 159.

19 Влаховић, Т. М. (2007) Утјецај нових технологија на функцију односа с јавностима, Медианали, Дубровник: Свеучилиште у Дубровнику, стр. 170; http://hrcak.srce.hr, 07.05.2012.

20 Исто, стр. 170.

21 Haig, M. (2001) The Essential Guide to Public Relations on the internet, United States, Milford: Kogan Page ltd.; 11.01.2012., http://books.google.rs/ books.

22 Исто, стр. 1; 12.01 .2012$. 
е-ПР-а, аутор закључује, с правом или не, да би све што радимо онлајн требало да се сматра ПР активношћу. На интернету сте перманентно изложени спољашюем свету. У стварном свету можете своју канцеларију да сакријете од љубопитљивих очију али када сте на интернету - ви сте у-на медију. И све ито поставите онлајн утиче на вашу penymaunjy... ${ }^{23}$

\section{Хоћемо оно што хоћемо - када ми то хоћемо}

Мр Бернард Миочић (Задар, ОТП банка) истраживао је медије и моделе односа с јавношћу на интернету, 2008. године, у раду Модели односа с јавношћу у онлајн окружењу. ${ }^{24}$

Тежиште истраживања било је на двосмерно - интерактивној комуникацији и остваривању дијалога, а испитивано је до које мере и са каквим успехом се постојећи офлајн (offline) модели односа с јавношћу, користе у комуникацији интернетом? Резултати спроведеног истраживања, показују да запослени у ПР службама још увек највише користе интернет као модел јавног информисања и да нису, у довољној мери, препознали најважнију карактеристику коју нуди новомедијско окружење - интерактивност. Успостављање и вођење оваквог вида комуникације је задатак запослених у сектору односа с јавношћу. Интернет, закључује овај аутор, сам по себи не води у нове облике комуникације. ${ }^{25}$

Донедавно је комуникацијски однос текао према начелу: Добит ћете оно што имамо кад вам ми будемо то дали. Данас вриједи нова парадигма: Хоћемо оно што хоћемо када ми то хоћемо. ${ }^{26}$ Овде је, дакле, реч о комуникацији која је усмерена према кориснику (receiver-driven communication), што значи да јавност бира само поруке које је занимају, док остале занемарује. Бернард Миочић, као и већина истраживача који су писали о онлајн односима с јавношћу, као њихову јединствену карактеристику издваја - постепени нестанак потребе за посредницима у преношењу поруке - најчешће - новинарима. С друге стране, новинарска вештина и искуство - да изаберу и процене вредност информације, као и да је пренесу даље - изузетно је драгоцена у ери екранске културе и информацијске презасићености. Оно што односи с јавношћу сад требају јест нов начин промишььања истих-интерактивно и умрежено. Развој он-лајн јавности

23 Исто, стр. $3 ; 12.01 .2012$.

24 Миочић, Б. Модели однса с јавношћу у онлајн окружењу, 06.05.2012., http://hrcak.srce.hr/

25 Исто, 16.05.2013.

26 Исто, 06.05.2012. 
и све већи онлајн проток информација између организација и јавности значајни су изазови с којима се суочавају сувремени односи с јавношћу... Тај нови облик комуницирана надилази ограничења као што су простор и вријеме, омогућује нелинеаран приступ многим изворима информаџија као и изравну комуникацију свих корисника мреже, закључује Бернард Миочић. ${ }^{27}$

Нове медије и односе с јавношћу, истраживала је и Рената Деметерфи Ланчић (Renata Demeterffy Lančić), сарадница на Факултету политичких наука у Загребу. Анализирала је и тумачила значење нових комуникацијских технологија с аспекта развоја плуралне јавне сфере, те односа с јавношћу, као једног типа комуникацијског деловања. У опћем друштвеном контексту, гдје су медији изгубили своје примарно значење, јавља се потреба постојања независних, слободних сустава комуницирања. Управо у таквој ситуацији нове комуникаиијске технологије, првенствено ширење интернета, отварају могућности новом развоју комуницирања јавности. Блогови, веб форуми, веб-странице, онлајн(оnline) магазини, имејл (е-таil) листе, чет (chat) собе, друштвене мреже итд., представљају нове облике јавног комуницирања, гдје грађани имају могућност равноправног судјеловања у јавној сфери, у којој комуникачија поновно постаје размјена мишьена, а мрежа има потенцијал јавне расправе као темеља демокраиије. ${ }^{28}$ Рената Деметерфи Ланчић сматра да су нови медији, између осталог, значајни и на подручју односа с јавношћу, јер унапређују комуникацију и утичу на друштвене промене, али указује и на могућности манипулације које из њих произлазе - За разлику од традиционалних метода, нове методе далеко су суптилније те је једина могућност заштите корисника рачунала у њиховој правилној едукаиији. ${ }^{29}$

Иако многи аутори сматрају да су односи с јавношћу усмерени на промене парадигме производње, која се у новом, дигиталном окружењу темељи на производу, ауторка закључује да се модел деловања односа с јавношћу није битно променио. Чињеница је да нове околности захтијевају дугорочан, персонализирани однос с потрошачем, утемељен на сталној интеракцији, који се налази испред традиционалног приступа који је у први план стављао производе, услуге, цијену

27 Исто, 06.05.2012.

28 Demeterffy Lančić, R. (2010) Novi mediji i odnosi s javnošću, Medijske studije, Zagreb: Sveučilište u Zagrebu, Fakultet političkih znanosti, str. 167.

29 Исто, стр. 157. 
u nрофит..$^{30}$ Ауторка уочава и два темељна проблема који настају у спрези односа с јавношћу и нових медија, и на које треба посебно обратити пажњу. Први се проблем односи на питање етичког оквира (истине и веродостојности написаног) а други проблем који одликује сваку иновацију јест потреба комериијалног сектора да из ње извуче профит. ${ }^{31}$

Робин М. Мејхал (Robin M. Mayhall), књижевница и новинарка, сматра да за практичаре из области ПР-а, интернет представља највећу иновацију свих времена, која омогућава скоро сваки облик комуникације који можемо да замислимо, континуирано повећава популарност, нуди могућности за професионални развој ПР практичара, могућности за спровођење онлајн истраживања и најважније - могућности да ширимо (сејемо) своје поруке. ${ }^{32}$ Ова ауторка препоручује и бројне корисне линкове у вези са ПР-ом, од којих, издвајамо: сајт пр веб (prweb.com), ${ }^{33}$ веома посећена интернет адреса, са базом саопштења и вести, потом, пр плејс (prplace.com), ${ }^{34}$ сајт са бројним корисним информацијама, онлајн $n p$ (onlinepr.com), ${ }^{35}$ посвећен онлајн ПР-у, као и изванредан портал, чија је ауторка блогерка, ПР и маркетинг икона, Б. Л. Охман (B. L. Ochman), који је посвећен онлајн маркетинг и ПР стратегији, трендовима у области друштвених медија, као и интернет заједници. ${ }^{36}$

Овде можемо да наведемо и занимљив пример дигиталне медијске кампање Универзитета Салфорд, организоване поводом уписа, 2008. године, када је, уз израду засебног сајта и промоцију овог Универзитета на бројним друштвеним медијима, лансирана и вирална игрица симболичног наслова Радознали? и поднаслова - неограничене могућноcти... ${ }^{37}$ Игрица је била визуелно усклађена, на свим нивоима и веома пажљиво, са брендом Салфорд Универзитета. Такође, била је структуирана тако да подстиче друштвену интеракцију и коришћење алата за умрежавање, а све у знаку бренда Салфорд и са линком ка сајту овог универзитета. У дану када је посећен сајт са подацима, за потребе писања рада, више од 1, 5 милиона корисника одиграло је

\footnotetext{
30 Исто, стр. 158.

31 Исто, стр. 166

32 Mayhall, R. M. Public Relations on the Internet, 28.04.2012 http://www.docstoc.com/docs/4024889/Public-Relations-on-the-Internet

33 29.04.2012., http://www.prweb.com

34 29.04.2012., http://www.prplace.com

35 30.04.2012., http://www.online-pr.com

36 30.04.2012., http://www.whatsnextonline.com

37 13.05.2012., http://www.newgrounds.com/portal/view/403988
} 
игрицу, а од тог броја - тачно половина је следила линк и отишла на сајт универзитета. ${ }^{38}$ Саобраћај се на тој адреси драстично повећао. Посебно је био видљив успех у ширењу свести о програмима и постојању Салфорда и изван граница Велике Британије. Један од бројних посетилаца оставио је коментар - Да сам ближе - сигурно бих обишао Салфорд. A можда једног дана и хоћу. ${ }^{39}$ Предузеће Катапулт које је осмислило ову игрицу, и сајт дигиталне кампање Салфорда, добило је награду ДАДИ (за дигиталну изузетност), у 2008. години - за најбољу дигиталну медијску стратегију, познатог британског часописа ДРУМ (The Drum).

Очигледно је, када се анализирају овакве и сличне кампање, да се ствара и потреба за све већим бројем занимања и послова из области онлајн ПР-а, и то ову, иначе младу теоријску и практичну област, чини додатно занимљивом за истраживања. СЕО специјалиста (посао унапређења видљивости сајта на претраживачима), менаџер онлајн ПР кампања, менаџер задужен за друштвене медије (маркетинг и ПР), онлајн стратег - само су нека од њих.

\section{Зар ово није ваш посао?}

У угледном часопису Паблик Рилејшнс Ривју (Public Relations Review), Лаура Н. Хил (Laura N. Hill) и Кендис Вајт (Candace White) припремили су серију интервјуа са ПР професионалцима, о томе како виде вредности веба као комуникацијске алатке. Истраживање је показало да запослени у ПР сектору верују да сајт симболизује компетитивност компаније, побољшава њену слику и ојачава лични осећај професионализма. Такође, сматрају да је веб први контролисан масовни медиј односа с јавношћу у коме садржај стиже до масовне публике, али није довољно филтриран. Аутори пишу и о томе да бројни магазински чланци из тог периода, са насловима попут - Не дозволите да ПР контролише ваш веб сајт - указују на неку врсту надметања унутар саме организачије за контролу над вебсајтом, ${ }^{40}$ и наводе мишљење истраживача који су писали о томе да не треба дати одељењу за ПР контролу над веб сајтом јер ће га претворити у досадну корпоративну брошуру. ${ }^{41}$ Очигледно, 2000. године запослени у области односа с јавношћу, нису били превише заинтересовани за веб као комуникацијску алатку, био им

38 13.05.2012., http://www.katapult-studios.com/our-work/university-salford 39 Исто, 13.05.2012.

40 Hill, N. L. and White, C. (2000) Public Relations review No. 26, United States: Elsevier, p. 5.

41 Исто, стр. 5. 
је на тзв. $\sigma$-листи задатака, али су ипак увиђали значај и предности коришћења веба. Момии из одељена за информационе системе су направили сајт и поставили га, не трудећи се да то кажу било коме. Онда је веб постао славан. Почетна страна постала је видљивија, и екстерној и интерној јавности. Неко је требало да нахрани звер. Онда су момии из поменуте службе отишли у одељење за ПР и рекли - Зар ово није ваш посао? ${ }^{42}$

\section{Објави или страдаj - Publish or Perish}

Блогови се покрећу, од стране појединца или организациje, из бројних и веома различитих разлога. Посматрано из угла теме овог рада, они су одлично средство за промоцију производа, услуга и других садржаја, успостављање директне комуникације са корисницима, простор за размену идеја - драгоцена алатка за потребе ПР-а. Важне одлике блога су неутралност (претпостављена) и могућност остављања коментара, која подстиче друштвену интеракцију и стварање онлајн заједница, тзв. блогосфере. Уз то, блогови представљају користан алат за проналажење релевантних информација. Често блогове користе и различите врсте организаиија као додатак традиџионалним маркетиншким и ПР кампањама, управо због своје неутралности, а онда и кредибилитета који такав вид неутралности подразумијевa. ${ }^{43}$ Као сликовит пример, Рената Деметерфи Ланчић наводи покретање новог тематског парка посвећеног Харију Потеру, (Harry Potter) од стране компаније Универзал Орландо Ризортс (Universal Orlando Resorts). Наиме, 2007. године, ова компанија је ангажовала седам најутицајнијих блогера о Харију Потеру да пишу о парку а путем тајног вебкаста (webcast) договорени су елементи забавног парка. Овакав вид ПР кампање показао се као веома успешан - ускоро је 350 милиона људи чуло за нови парк, текстове ангажованих блогера преузимали су други блогери и медији, вест се брзо ширила а трошкови кампање били су минимални. ${ }^{44}$

Занимљив је, са аспекта односа с јавношћу, и данас већ чувени пример - кампања председника САД-а, Барака Обаме (Barack Obama), која се великим делом, веома успешно, водила у онлајн окружењу. Начин вођења поменуте политичке онлајн кампање, Барака Обаме, ускоро је ушао у литературу, и добио назив Обамаркетинг.

42 Исто, стр. 5.

43 Demeterffy Lančić R., нав. дело, стр. 159.

44 17.05.2010., http://www.universalorlando.com/harrypotter 
Драган Варагић је онлајн стратег и ПР консултант, предавач и блогер. ${ }^{45}$ И уз бројне савете, занимљиве и увек актуелне текстове који представљају веома корисно штиво за теоријско и практично бављење ПР-ом, на Варагићевом сајту налазимо и бесплатну ПДФ публикацију са најважнијим упутствима за писање блога - Блог основе. ${ }^{46}$ Један од веома читаних постова, у вези са онлајн репутацијом, на пример, је текст под називом Управљање е-репутацијом у пракси: Успон и пад "утицајних" твитераша и блогера, ${ }^{47}$ - Често се заборавља да је на друштвеним мрежама најважнија монета - успостављање поверења, или другачије речено, колико вам верују у оно што причате, радите, креирате, пишете онлајн... Проблем код те крилатице “успостављање поверења" је ито се додатно заборавља да је то поверење потребно и одржавати, јер се оно губи у секундама. ${ }^{48}$ Друштво Србије за односе с јавношћу (ДСОЈ) објавило је недавно Препоруке о односима с блогерима. Важан аспект ових препорука, сматра Варагић, јесте прича о прикривеној промоцији, односно ситуације у којима се не зна да ли је креиран садржај плаћен да би се поставио на блог или представља аутентично мишљење креатора блог садржаја. ${ }^{49}$ Овај аутор, као и многи други истраживачи, као велику предност интернета у ПР послу, види чињеницу да су ефекти и интересовања корисника - прецизно мерљиви. Могуће је знати шта (и колико) интересује посетиоце презентације, колико је особа посетило сајт у одређеном времену, какве су техничке карактеристике рачунарских система са аспекта видљивости презентаџије у окружењу корисника, итд. ${ }^{50}$

Блогови, као активност односа с јавношћу, помажу, дакле, да се изгради поверење, да се успоставе и одрже квалитетни пословни контакти, да се прикупе важне повратне информације - што у данашњем свету представља најтежи али и најважнији задатак ПР-а. Добро вођење блогова доноси предности, давањем корисних информащија и информација које “траже” ангажман (коментарисање) ${ }^{51}$... а креирање

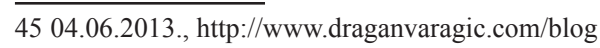

46 Варагић, Д. Блог основе, 12.12.2012., http://www.draganvaragic.com/blogosnove

47 15.06.2013., Варагић, Д. http://www.draganvaragic.com/blog/upravljanjeonline-reputacijom-u-praksi-uspon-i-pad-uticajnih-tviterasa-blogera

48 Исто, 01.07.2013.

49 Исто, 15.06.2012.

50 Варагић, Д. Блог основе, 04.02.2013., http:// www.draganvaragic.com/ blog-osnove

51 Исто, 05.02.2013. 
адекватних садржаја путем коментара на форумима, блоговима, сочијалним мрежама, као и креирање сопствених корпоративних блогова, директно утиче на повећане онлајн кредибилитета и посећености веб сајтова. ${ }^{52}$

Милоје Секулић, интернет и пословни консултант, издваja, као посебно занимљив, блогерски пројекат Моје дојке су $O K$ : вебсајт, Фејсбук (Facebook) фан страницу, присуство на Твитеру (Twitter) и комбинацију онлајн са офлајн активностима. Уз бројне блогове и онлајн магазине о овој акцији, наводи Секулић, писале су и дневне новине (Прес, 24 сата), а учеснице пројекта су гостовале на Првој ТВ и Хепи (Нарру) телевизији. Ова, прилично успешна, онлајн кампања остварена је без класичних ПР алата, као што су саопштење за медије, конференција за новинаре итд. Милоје Секулић је писао о бројним примерима добре праксе односа с јавношћу на интернету, а о некима од њих биће више речи у наредним поглављима рада.

Резултати студије Брајана Смита (Brian G. Smith), са Универзитета у Хјустону (University of Houston), која је посвећена еволуцији блогосфере, показали су да сарадња са блогерима доноси предности ПР сектору и организацији. У овом истраживању интевјуисано је десет блогера, а постављена су два основна питања - зашто водити индивидуални блог и како блогери виде ПР интересе? Блогери виде блог као медиј за сопствено изражавање, повезивање са заједницом и могућност за дељење и размену. Такође, неретко, осећају и притисак да пишу и објављују - објави или страдај - (publish or perish). ${ }^{53}$ Интервјуисани блогери су говорили о томе да је приличан број људи угасио своје блогове када је тај притисак постао превише интензиван. Једна испитаница је одговорила да је свесна напора ПР практичара да добију бесплатан публицитет и да је та танка граница коју она не би прешла - када би јој неко послао поруку са реченицом - Зар не би било дивно када би ти написала овако нешто? ${ }^{54}$ Блогери који сарађују са ПР професионалцима кажу да гледају да избегавају притисак - да се њихове организације стално приказују у лепом светлу. Осетљиво је то питање - јер не можете да им се супротстављате а не можете ни да радите све онако како би они хтели. Потребно је наћи баланс. ${ }^{55}$

\footnotetext{
52 Исто, 05.02.2013.

53 Smit, B. (2010) The evolution of the blogger: Blogger considerations of public relations-sponsored content in the blogosphere, Public relations review No. 36, United States: Elsevier, p. 175.

54 Исто, стр. 176.

55 Исто, стр. 177.
} 
Мотивација испитаника се мењала, како су стицали више искуства у блогосфери. Тако је и са односима с јавношћу на почетку сте узбуђени због юихове пажне и предлога а онда, временом, постанете селективнији у вези са юиховим садржајем. ${ }^{56}$

Најзад, резултати овог истраживања су показали да, иако изгледа нелогично, напори да одушевимо блогере са нпр. привлачним насловима - не морају да резултирају добрим пр-блогер односом, јер се овакве ПР активности често виде као сасвим безличне и незанимљиве.

\section{Онлајн ПР у Србији}

У Србији се праксом онлајн односа с јавношћу баве маркетинг и ПР агенције (као основном или додатном делатношћу), организације, појединци и компаније. Међу интернет ПР практичарима, издвајају се, према текстовима, популарности (месту и угледу које заузимају у српској интернет заједници), објавама и студијама случаја из ове области - Драган Варагић, Милоје Секулић, Драгана Ђермановић, Миодраг Костић, Иван Ћосић... Друштво Србије за односе с јавношћу има своју онлајн ПР секцију, а крајем априла месеца 2012. године усвојен је и поменути документ о препорукама о односима са блогерима, са ицивем успостављана што квалитетнијег односа са блогерима, као занимљивом и осетььивом јавношћу. ${ }^{57}$

Драгана Ђермановић пише, и теоријски и практично засноване, интересантне и корисне текстове о односима с јавношћу на интернету. На блогу о ПР-у, конверзацији, новим медијима, и ПРимерима комуникацијске праксе - наћи ћете више него што сте очекивали, али и даље мағе него што је потребно да се разуме вибрантно конверзаиијско окружење.$^{58}$ Поверење и квалитетан садржај представљају основу за стварање онлајн кредибилитета и репутације, а прецизност, поштовање и професионализам услове sine qua non е-ПР-а, пише, између осталог, на овој, за истраживаче ове теме, веома драгоценој адреси. А на једно од кључних питања дигиталног ПР-а - Које су особености онлајн дијалога и вишесмерне, транспарентне, реал тајм нет (real time net) конверзаиије? ${ }^{59}$ Драгана Ђермановић одговара, на следећи начин: Овај облик комуникаиије надилази ограничења

56 Исто, стр. 177.

57 Препоруке о односима с блогерима, 12.06.2013., http://www.slideshare. net/PRSrbija/preporuke-oodnosimasblogerima

58 01.05.2013., http://www.draganadjermanovic.com

59 Исто., 02.05.2012. 
као што су простор и време, омогућава нелинеаран приступ многим изворима информација, као и директну комуникацију свих корисника мреже. ${ }^{60}$

Од различитих и веома бројних активности Драгана Варагића (неке су поменуте у претходном поглављу рада), за ПР практичаре (и не само за њих), можда је посебно занимљив сервис за онлајн дистрибуцију саопштења ПРобјаве. ком (PRobjave.com) ${ }^{61}$ Отварањем бесплатног налога на овом сервису, у могућности сте да читате и примате комплетна саопштења, као и да самостално постављате ваша саопштења за јавност. Предности коришћења оваквих и сличних сервиса су бројне - повећање видљивости саопштења, повећање броја објављених саопштења и посећености вашег веб сајта итд. Саопштења која су прилагођена Веб окружењу имају могућност да буду прочитана од стране заинтересованих крајюих корисника, поред тога што су видљива и представницима (онлајн) медија. Да ли ће ваше саопштење одабрати неки уредник или новинар, ипак на крају зависи од тога колико је то саопштење вредно као вест (newsworthy). ${ }^{62}$ За праћење интернет медија за потребе ПР професионалаца, сматра Варагић, неопходно је - креирати листу онлајн медиja, пратити медије и најчитаније теме, пратити друштвене медије и садржаје које стварају сами корисници, користити онлајн мониторинг и прес клипинг на интернету и радити ручну евалуацију броја онлајн објава. Сајт draganvaragic. $c^{6}{ }^{63}$ изванредан је извор савета, идеја, предлога и критичког промишљања онлајн ПР праксе и теорије. На пример, у презентацији Стратегија креирања онлајн садржаја, ${ }^{64}$ између осталог, пише да корисници на вебу не читају, већ само скенирају садржај (задржавају се у просеку тридесет секунди на страни), и да је веома важно када пишемо ПР саопштења или објаве за веб, да водимо рачуна о наслову, кључним речима и линковању. Наравно, систем писања зависи од захтева специфичног онлајн медија (друштвени медиј, сајт, блог и слично). Садржаји на интернету се, закључује Варагић, креирају водећи рачуна, пре свега, о корисницима.

Милоје Секулић је на мрежи активан и присутан на различитим адресама, али као полазна - може да послужи адреса

60 Исто, 02.05.2013.

61 27.03.2012., http://www.probjave.com

62 Варагић, Д. Креирање онлајн саджаја, 13.06.2012., http://www.slideshare.net/konferencije/dragan-varagi-kreiranje-online-sadraja-presentation

63 06.2013., http://www.draganvaragic.com

64 Исто, 14.06.2012. 
сајта Интернет агенције. ${ }^{65}$ У једном од бројних, и веома занимљивих, текстова посвећених ПР -у, Милоје Секулић, између осталог, пише да је посао ПР-а - подршка пословању, а онлајн ПР-а - такође. У овој једноставној реченици сумирана је основа и суштина добрих односа с јавношћу - било у онлајн или офлајн свету. Као један од првих примера домаће е-ПР кампање - овде можемо да наведемо промоцију новог паковања Коло кекса, уз онлајн видео игру Кекс на кекс, коју је реализовао Милоје Секулић, у то време запослен у Мекен Ериксон-у (MCann Erickson). Анализа коју су припремили показала је да конзументи кекса - прилично много времена проводе на интернету а играње онлајн игара је на трећем месту интернет активности ове циљне групе. У домаћој ПР пракси до тада је веома ретко коришћен овакав приступ циљној групи - млађим особама (15 до 35 год.) које доста користе интернет, најчешће у потрази за забавом. Циљеви онлајн комуникације били су - информисање циљне групе, стварање емоционалне везе, креирање word of mouth ефеката. Посебна пажња посвећена је особама које радо шире информације о новим занимљивим веб пројектима ${ }^{66}$ на сервисима Фејсбук и Твитер, па су у ПР алат уграђене функционалности које то лако омогућавају. Посетиоци више од 250 најпосећенијих домаћих сајтова обавештени су, током овог периода, о игри и наградама за најбоље играче, коришћењем система за контекстуално оглашавање - етаргет.рс (etarget. $r s) .{ }^{67}$ Ова врста текстуалних огласа заснива се на правилном одабиру кључних речи и пласирању квалитетних порука, па се може посматрати као специфичан ПР алат. Резултати су били следећи - током првих месец дана игра Кекс на кекс је одиграна преко 35.000 пута, а свој резултат су забележила 1.253 играча. Ова кампања односа с јавношћу на интернету била је веома успешна, за тадашње прилике, сматра Милоје Секулић, пре свега захваљујући креативној употреби интернета, истраживању навика корисника и добром познавању домаћих веб локација. Дакле, као и реалном свету - иновативност, знање и креативност су кључне речи за успех - и у виртуелном свету.

Примери који показују да је могуће скренути пажњу јавности и, што је можда много важније, сачувати је, једноставним и јефтиним средствима, у дужем временском периоду су: поплава у селу Јаша Томић (2005 године) и земљотрес у Краљеву (2010). Истог дана када је почела поплава у

65 10.06.2013., http://internetagencija.rs

66 Секулић, М. 17.04.2012., http://www.pr.org.rs/upload/documents/12PRijem10video igra Keks na keks

67 12.06.2013., http://www.etarget.rs 
локалној кафани направљен је кризни штаб а момак из места који је знао понешто о изради сајтова направио је прву, рудиментарну верзију веб сајта посвећеног поплави и лансирао га модемском везом преко јединог телефона који је радио. На сајту су из сата у сат објављиване фотографије ca терена. ${ }^{68}$ Шта је 2005. године од алата било на располагању? Веб сајтови, банери и форуми. ФБ (Фејсбук)и Ју тјуб (You tube), код нас, нису имали популарност коју имају данас, пре свега, због слабих интернет веза. Године 2010. снажан земљотрес је погодио Краљево. Шта је тада било на располагању? Портали за дељење фотографија, ФБ, Јутјуб, веб сајтови, Твитер, блогови... моћни активистички алати, са огромним виралним потенцијалом и великим мултимедијалним могућностима. Све наведене алатке помогле су да се о овом догађају, великом брзином, припреме адекватне информације и доставе огромном броју људи, као и да се пажња и интересовање јавности одрже у дужем временском периоду.

\section{Друштвени медији у функиији односа с јавношћу}

Друштвени медији су веб сервиси који нуде корисницима бројне канале комуникације, у виду самопрезентације и стварања властите публике или интерактивне комуникације. Друштвене медије чине: форуми, блогови, микроблогови, друштвене мреже, онлајн удружења итд. а свакодневним стварањем нових друштвених сервиса ова се листа непрекидно допуњује. Међутим, оно што у ствари чини друштвене медије јесу појединци - чланови, блогери, твитераши итд. Као скуп различитих веб-сервиса друштвени су медији постали утјецајан скуп алата на друштвено мишьене, па и стварање трендова. ${ }^{69}$ Познате платформе, сервиси и друштвени медији, попут PCC(RSS), Вики, Јутјуба, ФБ, блогова и сл., развиле су се из потреба тржишта те довеле до глобалног друштвеног умрежавања и омогућиле представљање јавности - готово бесплатно. Овако хетерогено дигитално окружење утиче, на веома различите начине и на различитим нивоима, и на област односа с јавношћу. Дјеловањем на странииама друштвених мрежа односи с јавношћу досегнули су нову разину те су приморани усвојити нове методе и технике. Три начела друштвених мрежа - информирағе, увјеравање и повезивање - почињу вриједити и као начела

68 Секулић, М. 09.03.2012., http://www.slideshare.net/Internetagencija/drustvene-mreze-i-mediji-zasto-su-toliko-bitni

69 Demeterffy Lančić, R. (2010) Novi mediji i odnosi s javnošću, Medijske studije, Zagreb: Sveučilište u Zagrebu, Fakultet političkih znanosti, str. 159. 
новог облика односа с јавношћу. Стручњаци на овом подручју схваћају да квалитетна маркетиника кампања не може заобићи огламавање на Фејсбуку и интернету опћенито. ${ }^{70}$

Светска искуства указују на чињеницу да се оглашавање, али и односи с јавношћу постепено селе у домен интернета. Квалитетни и озбиљни односи с јавношћу, те маркетиншка кампања, не могу игнорирати друштвене медије. Примјер су агенције односа с јавношћу које прилично интензивно у задње вријеме користе Фејсбук и Твитер. Трајно оглашаване на интернету обухваћа Твитер, Фејсбук, ажурираюе властитог блога или веб-странице, те кампағу на једној или више тражилица. Тиме се, можемо закључити, претежито дјелатност односа с јавношћу, маркетинга и оглашавањ а сели у виртуалну домену и сама постаје конститутивни елемент друштвених мрежа. ${ }^{71}$

У раду Друштвени медији као маркетиншки алат, ${ }^{72}$ Бојан Пајић, пише о ФБ, Твитеру и ћаскаоницама (chat rooms), као добрим и моћним ПР и маркетиншким алатима а Фејсбук посебно издваја као добар алат за креирање специјалних догађаја и веома користан у кризним ситуацијама. Сајтови за дељење садржаја - попут Диг.ком (Digg.com), СтамблАпон. ком (StumbleUpon.com), Делишес.ком (Delicious.com), Фликр. ком (Flickr.com), Јутјуб.ком итд., сматра поменути аутор, такође су драгоцени за односе с јавношћу, као и промоција путем форума. Подстицање и одржавање онлајн комуникације је неопходно да би се остварио континуиран и квалитетан однос са корисницима. А за то је потребно време и стрпљење.

Мр Весна Опавски, директорка сајта медија центра, одржала је серију предавања Интернет ПР за НВО, која су била посвећена онлајн ПР-у у невладином сектору. Данас је неопходно присуство организације на друштвеним мрежама а разлога је много - сматра Опавски - велика видљивост рада организације, формирање јавних ставова о организацији или бренду, двосмерност, повратна спрега, могућност неформалне комуникације итд. Када је реч о комуникацији путем Фејсбука важно је да покушамо да створимо онлајн заједнице и да подстичемо дијалог. Предности и могућности су бројне - догађаји се добро котирају (обезбеђено интересовање свих укључених), имамо могућност да тражимо

\footnotetext{
70 Исто., стр. 161.

71 Исто., стр. 162.

72 Пајић, Б. Друштвени медији као маркетиншки алат, 11.05.2013., http:// www.scribd.com/doc/34598145/Dru\%C5\%A1tveni-mediji-kao-marketin $\%$ C $5 \%$ A 1 ki-alat
} 
мишљење заједнице о различитим темама, да спроведемо онлајн анкету, организујемо фото-конкурс, направимо фејсбук апликацију, и сл.

Друштвени медији су постали обавезан алат сваког ПР меначера. Ови алати олакшавају юихов посао и чине га много ефикаснијим. ${ }^{73}$

Анализирајући 653 твитова који садрже речи односи с јавно$w \hbar y$ или акроним ПР, циљ рада ${ }^{74}$, који су објавили истраживачи одељења за комуникације Фабра универзитета у Барселони (Pompeu Fabra University, Barcelona), био је посвећен дискурсу односа с јавношћу на Твитеру. Тачније, како поменути друштвени медиј доприноси развоју теорије и праксе односа с јавношћу? Студија (2009) је показала да се главне активности компанија у области односа с јавношћу на платформама за нано-блоговање, воде са циљем изградње и стварања позитивне слике, уз постојеће канале комуникације. Резултати су такође показали да је Твитер постао ефикасан канал за динамизацију тржишта рада за ПР послове као и да постоји тенденција убрзаног раста броја огласа и пријава за ПР послове на овој платформи. Такође, изненађујуће је мали број твитова студената односа с јавношћу, који траже информације у вези са студијама или коментаришу курсеве које слушају на факултету. Подаци добијени у овом истраживању показали су да је Твитер, у ПР-у, више медиј за професионалну употребу него платформа која подржава и фаворизује теоријски развој области, макар индиректно.

\section{Најновије ВС најважније вести}

На подручју интернета можемо уочити посве нови модел комуницирања у којем су актери стварања вијести многобројни, а улога новинара постаје значајнија у смислу објективног и транспарентног филтрирања порука. У креираюу вијести на страни сфере јавности судјелују онлајн друитвене заједнице равноправно с индивидуалним власницима блогова, док одјели односа с јавношћу у својој комуникацији дјелују - како на изворе информација, на новинаре, тако и на онлајн друштвене заједнице и власнике блогова. ${ }^{75}$ У свом критичком промишљању нових медија, Рената Деметерфи Ланчић закључује да само уколико су приче веродостојно

73 Исто, 17.04.2013.

74 Xifra J. and Graub, F. (2010) Nanoblogging PR: The discourse on public relations in Twitter, Public Relations Review No. 36, 171-174, United States: Elsevier Inc., p. 3.

75 Demeterffy Lančić, R. (2010) Novi mediji i odnosi s javnošću, Medijske studije, Zagreb: Sveučilište u Zagrebu, Fakultet političkih znanosti, str. 165. 
представљене - деловаће истинито и преносиће се даље. Тада је један задатак ПР-а обављен.

Као посебно занимљив феномен, Милоје Секулић истиче тренд који на специфичан начин повезује управо офлајн и онлајн медије - новинари користе и прате друштвене медије, све више, као извор информација или идеја за причу. Долазимо до закључка да је у редакцијама дневних новина установљено радно место "дописник са друштвених мрежа"... ита је неко "рекао на друштвеној мрежи” - постаje вест. ${ }^{76}$ Дакле, овај тренд, иако није предмет истраживања овог прегледа, треба имати у виду када се анализирају ПР пракса и теорија на интернету. Јер, подсетимо се, радију је требало 38 година да дође до 50 милиона корисника, телевизији 13 а интернету - свега 4 (од 1990). Фејсбук је за 4 године стигао до 100 милиона корисника. ${ }^{77}$

У дигиталној ери, новинари траже нове идеје и информације на интернет страницама, закључује Рената Деметерфи Ланчић. С једне стране, новинари као субјекти извештавана полако нестају, али, с друге стране, њихова улога постаје посебно значајна, јер управо они преузимају терет оцене веродостојности вести. Тиме је на дјелу својеврстан парадокс - због интернета и друштвених мрежа имамо већу слободу изражавања и више плурализма, али истодобно имамо маюу слободу медија, односно квалитетних, вјеродостојних информащија. Други парадокс карактеристичан је за дигитални садржај јер вијести које настају размјеном информација умноженим каналима више нису нужно и најважније вијести, него најновије вијести, па темељна мјерна јединииа постаје тренутак појаве вијести, а не њезин садржај. ${ }^{78}$

Ипак, одговорност за процену и евалуацију информација не би требало да буде само обавеза новинара већ, у складу са могућностима, и других корисника мреже. У том смислу, веома је важна континуирана едукација, не само о техничким предностима и могућностима, него и о начинима и критеријима проијене квалитете, вјеродостојности и релевантности информащија с којима се свакодневно суочавају, те које сами стварају и дистрибуирају. ${ }^{79}$

\footnotetext{
76 Секулић, М. Излагање на семинару: е-ПР за НВО, Београд, Медија центар, 13.02.2012.

77 Исто, 13.02.2012.

78 Demeterffy Lančić, R. (2010) Novi mediji i odnosi s javnošću, Medijske studije, Zagreb: Sveučilište u Zagrebu, Fakultet političkih znanosti, str. 166

79 Исто, стр. 168.
} 
У раду Комуникащија са корисницима у времену промена, Томас Бломстер и Хана Најберг, (Thomas Blomster, Hanna Nyberg), закључују, између осталог, да је у дигиталном 21. веку неопходно да организације, без обзира на величину и оријентацију, користе интернет за односе с јавношћу. Али никако не треба искључивати традиционалне медије. ${ }^{80}$

Времена у којима су активности односа с медијима, уључујући и гађање (pitching) новинара, причама и информацијама, биле у основи односа с медијима, данас су очигледно давно иза нас. Традиционални односи са медијима губе своју доминацију у ПР планирању. Група аутора у раду посвећеном анализи утицаја социјалних медија на праксу односа с медијима, анализира нови тренд - хватање медија (теdia catching). Наводе, између осталих, и пример експертског сервиса XAPO (HARO), који служи новинарима који траже информације и изворе, али и запосленима у области ПРа. ХАРО група је креирана на Фејсбуку, у новембру 2007. године а основао ју је Питер Шанкман (Peter Shankman) ${ }^{81}$ Уместо да начине реплику традиционалног медија, где ПР посленици шаљу своје идеје за причу новинарима, они су се одлучили да подстичу новинаре да им шаљу захтеве за специфичним информацијама. Група је једноставно форматирана - као листа могућности која се шаље медијима који су се пријавили да добијају те информације. А листа медија са којима сарађују је прилично дугачка и респектабилна. ХАРО такође допушта обичним људима, који се не баве професионално комуникацијом, да се прикључе и постану извор. Без наплаћивања, овај сервис повезује медије директно са изворима, без посредника. Када су прерасли ФБ, прешли су на мејлинг листе. Користећи их, новинари су тражили сасвим специфичне садржаје, радећи на одређеним причама, истовремено. Према подацима из 2009. године, сервис је имао 80000 извора, 30000 новинара и 3000 упита месечно.

Очигледно, борба за пажњу новинара и медија - остаје. Само, ПР сада тражи приче које траже новинари који су релевантни за њихову организацију.

80 Blomster, T. and Nyberg, H. (2005) Comunicating with customers in the times of change, Sweden, Lulea: University of Technology, p. 32.

81 28.04.2012., http://www.helpareporter.com 


\section{Шта је најважније што можете да урадите? Cлушиајте $^{82}$}

Нове технологије, дигитализација и глобално умрежавање, очигледно су извршиле (и врше), снажан утицај на односе с јавношћу. Бројне могућности флексибилног и, за поједине циљне групе, специфичног обликовања дигиталне комуникације, донело је ПР - у, дигитално доба. Нови медији особито су важни на подручју односа с јавношћу, с обзиром на то да унапређују комуницирање, утјечу на соиијалне промјене, а у друштву доводе и до развоја нових димензија комунииирања. Није случајност да управо у вријеме развоја нових медија индустрија односа с јавношћу биљежи свој највећи раст. ${ }^{83}$ Односно, посао ПР се променио ${ }^{84}$, како је, једноставно и сасвим исправно, закључио Дејвид Мирман Скот (David Meerman Scott), након разматрања нових правила маркетинга и односа с јавношћу, у екранској ери.

Иако није једноставно да издвојимо, у закључку овог рада, најважније принципе добре онлајн ПР комуникације, јер они зависе од бројних околности, нека основна правила су ипак сасвим јасна. Темељна и континуирана припрема и планирање, квалитетан и аутентичан садржај, који ће бити намењен пажљиво одабраној циљној групи, пласирање и ширење припремљених информација, доследност и веродостојност порука на свим платформама (онлајн и офлајн), добро познавање и креативна употреба нових, дигиталних технологија и сервиса, перманентна едукација, континуирано онлајн присуство и спремност да у сваком тренутку одговоримо на питања и захтеве које нам корисници шаљу... Или, како је препоручено у презентацији о значају онлајн односа с јавношћу: Ангажујте се - не рекламирајте се, допустите кориснику да бира - не диктирајте му. ${ }^{85}$

Мет Хајг уочио је још једну, изузетно важну, димензију онлајн ПР-а - релевантност. Морате да будете сигурни да је све што поставите онлајн релевантно за вашу публику... ${ }^{86}$ Овај аутор наводи пример - сајт Аnсолут вотке (Absolute

82 The importance of online PR, published by Sharma, K., Headstream (2008), 06.07.2013., http://www.scribd.com

83 Demeterffy Lančić, R. (2010) Novi mediji i odnosi s javnošću, Medijske studije, Zagreb: Sveučilište u Zagrebu, Fakultet političkih znanosti, str. 167.

84 Scott, M. D. Нова правила маркетинга и ПР-а, 26.05.2013, http://issuu. com/dvaidva/docs/pravila_marketinga

85 The importance of online PR, published by Sharma, K., Headstream (2008), 29.04.2013., http://www.scribd.com

86 Haig, M. (2001) The Essential Guide to Public Relations on the internet, United States, Milford: Kogan Page ltd.; 05.07.2013.http://books.google. 
vodka), који је у великој мери заправо посвећен клабингу (clubbing). И чини се ирелевантним на први поглед, јер се вотка скоро и не помиње. Али - није тако. Ова веб адреса је веома посећена јер је управо клабинг - тема која занима юихову циљну групу. Ако своје онлајн ПР активности ускладите са овим принципима - имаћете перспективан е-ПР.87

Веб је, подсетимо се, велики равнатељ, и сасвим мале, као и велике компаније - имају свој простор и место на интернету. ${ }^{88}$ И није претерано ако кажемо да је важно да водимо рачуна о свакој ситници, када је реч о нашем онлајн представљању - од речи и фотографија до аудио записа и мејлова које шаљемо. Све је важно.

Интернет технологије су, дакле, смањиле раздаљине између публике и организација. Августин С. Ихатор (Augustine $\mathrm{S}$. Ihator) сматра да је стратешким паковањем информациja, њиховом заштитом и добрим планирањем времена, као и контролисањем повратне комуникације и реакције - теже управљати данас, у информатичкој ери. Ихатор пише да су упркос изузетно бројним каналима комуникације - још увек потребни креативни односи с јавношћу. Јавности $u$ даље треба да их организачија обавести, да објасни, интерпретира информације. ${ }^{89}$ И додаје да је важно да, пошто комуницирамо са глобалном публиком, разумемо и познајемо различите културе комуникације, да би избегли неке грешке које могу скупо да нас коштају. На крају - и стари и нови комуникачијски приступи, морају стално да се меюају и конвергирају, на креативан начин, са својим јавностима, усклађено и ефикасно. ${ }^{90}$ Најзад, закључује поменути истраживач, кључна област у којој ПР професионалци морају да буду лидери је - преузимање одговорности за праћеюе (мониторинг) онлајн сервиса, укључујући и огласне табле, хиљаде нуз (nеws) група које постоје и сл. Игнорисање ове публике је равно пропуштаюу главне пориије вашег ПР потенцијала. ${ }^{91}$

rs/books?id=18fY9OS_dIC\&printsec=frontcover\&source=gbs_ge_summary_r\&cad $=0 \# \mathrm{v}=$ onepage $\& \mathrm{q} \& \mathrm{f}=$ false

87 Исто, 17.05.2013.

88 Grimborg, M. (2006) Public Relations and the Internet, United States, Illinois: Northern Illinois University, p. 6.; 24.06.2013., http://marygrimborg.com/ pdfs/scholarly.pdf

89 Ihator, S. A. Communication style in the information age, in: Corporate Communications: An International Journal, (2001), United States: Emerald Article, p. 199-204.; 25.05.2012. http://dx.doi.org/10.1108/13563280110409836

90 Исто, 14.06.2012.

91 Grimborg, М., нав.дело, стр. 7. 
Овде можемо да издвојимо једну област ПР-а, у којој су, можда, промене које су донеле дигиталне технологије, највидљивије - тзв. кризни ПР. Кризе и важна питања морају да буду комуницирани стејкхолдерима и у том смислу интернет је драматично променио ПР праксу. ${ }^{92}$ Постоје макар два забрињавајућа аспекта која се односе на кризно комуницирање - гласине се лакше (и брже) стварају и понављају, а вест о кризи се шири брже него икад. Информациони канали на интернету су се драстично повећали и информација која њима путује није уједначеног квалитета. Када је кризна ситуаиија, већина људи ће да похрли на интернет, да нађе тамо неку вест. И ако не види ништа о томе - сматраће да компанија не чини ништа да проблем реши..$^{93}$ Онда ће потражити вести на другом месту, на мрежи - које могу али не морају бити тачне. Поступајући према правилима доброг онлајн ПР-а, пожељно је да микросајт, посвећен кризи, буде унапред добро осмишљен и припремљен, пре него што криза наступи. Али, осим што је добро оруђе за борбу против кризе, интернет је и извор нових форми криза, стога запослени у односима с јавношћу морају континуирано да прате шта се говори и пише о њиховој компанији на вебу, наоружани солидним образовањем из различитих области и дисциплина. Такође, веома су важни одговарајући тренинзи и радионице за ПР професионалце - да би користили интернет као своју предност и у потпуности искористили потенцијале мреже.

Али, вратимо се публици. Нови медији охрабрују кориснике да промовишу и нуде своје производе и услуге онлајн - конзументи су данас трговци на мало на Ибеју (е-Вау), медијски продуцеенти и директори на Јутјубу, аутори на Википедиju, критичари на Амазон-у и Трипадвајзер-у (Amazon, Tripadviser)... И раде све ово и много вите на Мај спејс -y (My space) $и$ Фејсбуку. ${ }^{94}$ Чак им више није неопходан компјутер за то - мобилни телефони и технологије новијих генерација им то омогућавају. ${ }^{95}$ Дакле, јавност и публика су данас веома захтевни, траже аутентичност а не патетику и пропаганду. И све лакше и брже успевају да разликују прво од другог. Е-ПР даје сасвим нову перспективу и интернет маркетингу. Они

\section{2 Исто, стр. 10.}

93 Исто, стр. 11.

94 Вученовић, Т. (2011) Грађанско новинарство у дигиталном 21. веку, Култура бр. 132, Београд

95 Hennig Thurau, T., Malthouse, C. M., Friege, C., Gensler, S., Lobschat, L., Rangaswamy, A. and Skiera, B. The Impact of New Media on Customer Relationships, in: Journal of Service Research, (2010), United States, Arizona: Arizona State University 
који буду покушавали да имплементирају традицонална маркетиншка решењ а у сајберпростору - бориће се да преживе. Прави приступ данас мора да буде заснован на разумеваьу публике и помоћи - да и она разуме вас. ${ }^{96}$

...Како се међусобно повезујемо, многе вредности државенације уступиће своје место великим и малим електронским заједницама. Ми ћемо се социјализовати у дигиталном комшилуку у којем физички простор губи важност, а време добија другачију улогу ...97

\section{ЛИТЕРАТУРА:}

Блек, С. (2003) Односи с јавношћу, Београд

Blomster, T. and Nyberg, H. (2005) Communicating with customers in the times of change, Sweden, Lulea: University of Technology

Филиповић, В. и Костић Станковић, М. (2008) Односи с јавношћу, Београд: Клио

Grimborg, M. (2006) Public Relations and the Internet, United States, Illinois: Northern Illinois University

Haig, M. (2001) The Essential Guide to Public Relations on the internet, United States, Milford: Kogan Page ltd.

Hennig Thurau, T., Malthouse, C. M., Friege, C., Gensler, S., Lobschat, L., Rangaswamy, A. and Skiera, B. The Impact of New Media on Customer Relationships, in: Journal of Service Research, (2010), United States, Arizona: Arizona State University

Hill, N. L. and White, C. (2000) Public Relations review No. 26, United States: Elsevier

Ihator, S. A. Communication style in the information age, in: Corporate Communications: An International Journal, (2001), United States:

Emerald Article

Лалић, Д. (2010) Соиијалне мреже у функиији унапређења интерних односа с јавношћу, Нови Сад: Универзитет у Новом Саду, Факултет техничких наука

Demeterffy Lančić, R. (2010) Novi mediji i odnosi s javnošću, Medijske studije, Zagreb: Sveučilište u Zagrebu, Fakultet političkih znanosti

Негропонте, Н. (1998) Бити дигиталан, Београд

Smit, B. (2010) The evolution of the blogger: Blogger considerations of public relations-sponsored content in the blogosphere, Public relations review No. 36, United States: Elsevier

96 Heig, М. нав. дело, стр. 9

97 Негропонте, Н. (1998) Бити дигиталан, Београд, стр. 12. 
ТАМАРА ВУЧЕНОВИЋ

Талевић, Ђ. Односи с јавношћу: Онлајн ПР, у: Употреба информачионо-комуникачионих технологија у Републичи Србији, (2008), Београд: Републички завод за статистику Србије

Влаховић, Т. М. (2007) Утјецај нових технологија на функцију односа с јавностима, Медианали, Дубровник: Свеучилиште у Дубровнику

Вученовић, Т. (2011) Грађанско новинарство у дигиталном 21. веку, Култура бр. 132, Београд: Завод за проучавање културног развитка

Веб извори - избор:

http://en.wikipedia.org

http://hrcak.srce.hr

http://www.docstoc.com

http://www.prweb.com

http://www.prplace.com

http://www.online-pr.com

http://www.whatsnextonline.com

http://www.newgrounds.com

http://www.katapult-studios.com

Tamara Vučenović

University in Belgrade, Faculty of Philology, Belgrade

ONLINE PUBLIC RELATIONS

\begin{abstract}
In this paper a research was conducted on the topic of public relations in the digital era, especially the online one. Characteristics and peculiarities of public relations, the potential of the world wide web for E-PR and challenges and advantages of the digital communication are the main topics of the thesis. A short review of well chosen theoretical works that define and deliberate online public relations from a critical point of view is also presented here. The paper analyzes the potential of the web in dialogues, public debates and interactions, as well as the potential of blogs and social networks concerning public relations in the digital XXI century. The conclusion contains a critical reflection of the position, role and the potential of the online PR.
\end{abstract}

Key words: public relations, online, internet, social media, $P R$ comunication, information 